\title{
LADY FREYBERG: EXAMPLES OF HOW CONTEMPORARY COURTS IN ALBERTA APPROACH THE MODERN BUSINESS REALITIES OF THE FREEHOLD PETROLEUM AND NATURAL GAS LEASE
}

\author{
CHRIS SIMARD, ${ }^{*}$ DAVID HOLUB, ${ }^{* *}$ AND LARINA TAYLOR ${ }^{* * *}$
}

\begin{abstract}
The recently concluded case of Freyberg v. Fletcher Challenge Oil and Gas exemplifies the extent to which business realities have impacted the industry's ability to properly address legal challenges in a relatively inflexible historical jurisprudential context. The authors, all participants in the six-year Lady Freyberg action, detail the challenges facing modern oil and gas industry litigants given the somewhat rigid standards espoused by courts in the older jurisprudence. Given the rapidly shifting economic and institutional reality in the oil and gas industry, the authors reason, modern courts must approach such cases in a flexible manner and remain sensitive to the fact that business realities may have changed since the establishment of historical precedents.
\end{abstract}

\begin{abstract}
La récente cause Freyberg c. Fletcher Challenge Oil and Gas authentifie la mesure dans laquelle les réalités du monde des affaires influent sur la capacité de l'industrie d'aborder comme il se doit les problèmes légaux dans un contexte jurisprudentiel historique relativement rigide. Les auteurs, tous participants à la cause Lady Freyberg qui a duré six ans, expliquent en détail les problèmes auxquels les plaideurs de l'industrie gazière et pétrolière moderne fait face compte tenu des normes quelque peu rigides endossées par les tribunaux et les ressorts plus anciens. $V u$ l'évolution rapide de la réalité économique et institutionnelle de l'industrie gazière et pétrolière, les auteurs estiment que les tribunaux modernes doivent aborder ces causes avec souplesse et demeurer sensibilisés au fait que les réalités peuvent avoir changé depuis l'établissement des précédents historiques.
\end{abstract}

\section{TABLE OF CONTENTS}

I. INTRODUCTION . . . . . . . . . . . . . . . . . . . 299

II. A TAle of TWo Trials . . . . . . . . . . . . . . . . . . . . . . . . . . 300

A. THE History of the Litigation . . . . . . . . . . . . . . . . . 300

B. THE BACKGROUND FACTS . . . . . . . . . . . . . . . . . 301

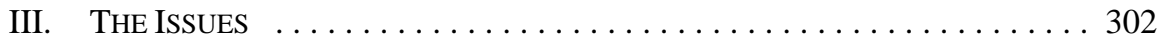

A. The Onus of Proof in Lease Termination Cases $\ldots \ldots \ldots . \ldots 302$

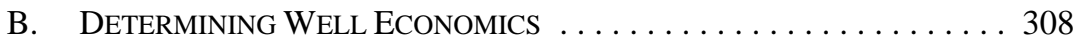

C. Measuring Damages in Lease Termination Cases . . . . . . 317

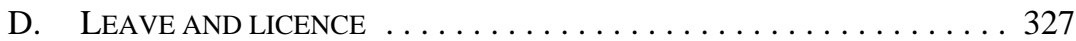

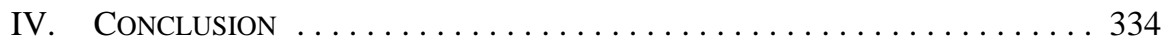

\section{INTRODUCTION}

The purpose of this article is to provide a detailed overview of the Freyberg $v$. Fletcher Challenge Oil and Gas ${ }^{1}$ freehold lease litigation (Lady Freyberg) that has only recently been concluded, some six years after it commenced. An understanding of this seminal case is crucial for all oil and gas industry participants in Western Canada. Not only did the case set a number of important legal precedents for the industry (giving rise to ten reported

* Partner, Bennett Jones LLP.

** Senior Legal Counsel, Apache Canada Ltd.

**** Legal Counsel, ConocoPhillips Canada.

2005 ABCA 46, 363 A.R. 35, leave to appeal to S.C.C. refused, 30874 (10 November 2005). 
decisions), ${ }^{2}$ but it also provides an instructive glimpse into how contemporary Alberta courts address modern business realities in the context of a relatively lengthy historical body of case law (some of it now more than 75 years old) in this now mature Canadian industry.

The authors were all intimately involved in the case from the beginning and have had a unique insider's view of the legal issues, the evidence, the trial strategy, and the practical ramifications of the case. This article shares that insight.

The article is not intended, however, to simply comprise a longer-than-usual case comment. In addition to the practical ramifications of the case, the novel legal developments, and litigation strategy insights that can be gleaned from the case, there is a broader issue, or tension, apparent in the major judgments in Lady Freyberg. This tension exists between what some have advanced as a tendency in older Canadian oil and gas jurisprudence to establish absolute "rules," rendering the law of freehold petroleum and natural gas leases sui generis and relatively fixed, and the inclination of contemporary Canadian courts to approach modern business realities in a sensitive, flexible, and contextual manner. The Lady Freyberg case demonstrated this tension in the context of a number of different legal issues: the onus of proof in lease termination cases; the determination of well economics; the quantification of damages in terminated lease cases; and the defence of "leave and licence."

\section{A Tale of Two Trials}

\section{A. THE HistORY OF THE Litigation}

The case involved two relatively lengthy trials, or more precisely, two phases of a bifurcated trial. The first trial took place in March and April of 2002, when the parties tried the issue of whether the petroleum and natural gas lease at issue (the Lease) was valid. After two weeks of trial, Romaine J. concluded in the First Trial Decision, that the Lease was valid. ${ }^{3}$ Lady Freyberg appealed and in February 2005, the majority of the Court of Appeal of Alberta overturned Romaine J.'s decision (Conrad and Ritter JJ.A. in the majority, O’Leary J.A. in dissent). ${ }^{4}$ In November 2005, the Supreme Court of Canada denied the defendants' application for leave to appeal, necessitating the second phase of trial - to determine the proper quantum of damages to be awarded to Freyberg. Justice Kent presided over the second phase of the trial in January and February of 2007 and rendered her decision in May 2007. ${ }^{5}$ The Second Trial Decision answered most, but not all, of the damages issues,

Freyberg v. Fletcher Challenge Oil and Gas, 2002 ABQB 692, 323 A.R. 45 [First Trial Decision]; Freyberg v. Fletcher Challenge Oil and Gas, 2003 ABQB 176, 337 A.R. 127; Freyberg v. Fletcher Challenge Oil and Gas, 2003 ABCA 208, 330 A.R. 130; Freyberg v. Fletcher Challenge Oil and Gas, 2005 ABCA 46, 363 A.R. 35 [Appeal Decision]; Freyberg v. Fletcher Challenge Oil and Gas, 2006 ABQB 614, 400 A.R. 11 [Freyberg QB]; Freyberg v. Fletcher Challenge Oil and Gas, 2006 ABCA 211, 391 A.R. 182; Freyberg v. Fletcher Challenge Oil and Gas, 2006 ABCA 260, 397 A.R. 235; Freyberg v. Fletcher Challenge Oil and Gas, 2006 ABCA 336, 401 A.R. 30; Freyberg v. Fletcher Challenge Oil and Gas, 2007 ABQB 80, [2007] A.J. No. 127 (QL); Freyberg v. Fletcher Challenge Oil and Gas, 2007 ABQB 353, 428 A.R. 102 [Second Trial Decision].

First Trial Decision, ibid.

Appeal Decision, supra note 2.

Second Trial Decision, supra note 2. 
and the parties subsequently reached a confidential settlement, concluding the litigation in the fall of 2007.

\section{B. THE BACKGROUND FACTS}

The dispute related to the freehold mineral title underlying Section 3-37-10W4M in the Province of Alberta (the Lands). The Lease was entered into on 13 November 1975, between the original lessors, Stella Margaret Woolley (the 1/3 freehold mineral owner of the Lands) and Noel Claude Fonnereau (the 2/3 freehold mineral owner of the Lands and Freyberg's cousin), and Voyager Petroleums Ltd. (Voyager) as lessee. ${ }^{6}$

Fonnereau bequeathed his undivided 2/3 share of the Lands and the Lease to Lady Freyberg in his will. The interests passed to her after his death in $1979 .^{7}$ The undivided $1 / 3$ interest of Woolley was transferred to NV Resources Corporation Ltd. (NV Resources) in 1988. ${ }^{8}$ As is relatively common in Alberta, a small portion of the freehold (surface and mineral) title in the Lands had been reserved for use as a school. Accordingly, Freyberg and NV Resources only owned title to 637 acres of the Lands. The County of Paintearth No. 18, successor to the original School District (Paintearth), owned the freehold mineral title to the remaining three acres of the Lands. Paintearth had entered into a petroleum and natural gas lease with Voyager at about the same time that the Lease had been entered into. The threeacre Paintearth lease was never challenged and Paintearth was never a party to the litigation. ${ }^{9}$

In October 1978, during the primary term of the Lease, Gascome Projects Ltd. (Gascome), Voyager's farmee, drilled a natural gas well in Legal Subdivision (LSD) 6 of the Lands (the 6-3 Well). ${ }^{10}$ At the time of drilling, a drill stem test (DST) was conducted in the Glauconite formation, and this indicated a steady flow at 5.065 million cubic feet per day. ${ }^{11}$ There was no infrastructure existing in the area and the 6-3 Well was immediately shut-in. This was a fate shared by tens of thousands of natural gas wells in Alberta at the time.

No further operations were carried out with respect to the 6-3 Well until 1998. By that time, Freyberg and NV Resources were the successors to the original lessors, and the interest of Voyager as lessee had devolved to no fewer than 13 different working-interest owners (the Defendants). None of the defendants had more than a 26 percent working interest in the Lease or in the 6-3 Well. Kalta Energy Corp. (Kalta), with a 15 percent working interest, was the operator. ${ }^{12}$

In the late 1980s and early 1990s, two other natural gas wells (the 10-33 Well and the 1134 Well), located within 1.5 miles of the $6-3$ Well, were tied in and did produce. One of the two was certainly in the same reservoir as the 6-3 Well, while the other may not have been (the expert evidence on the issue was conflicting and the issue was never determined by a

Ibid. at para. 4.

Ibid.

First Trial Decision, supra note 2 at para. 4.

Second Trial Decision, supra note 2 at para. 10.

Appeal Decision, supra note 2 at para. 152.

Ibid. at para. 16.

Freyberg QB, supra note 2 at para. 67. 
court). Both of the wells initially produced at relatively healthy rates, but watered out soon after.

In 1998, Fletcher Challenge Energy Canada Inc. (which later became Apache Canada Ltd. (Apache)) purchased its 25 percent interest in the 6-3 Well and the Lease from Poco Petroleums Ltd. (Poco), the successor to Voyager. By the late 1990s, Apache owned most of the infrastructure in the area around the 6-3 Well, including the regional gas plant. After its purchase, Apache initiated a tie-in of the 6-3 Well, along with 12 of the other wells it had also purchased from Poco, as part of a $\$ 25$ million capital program in the area. A 7.5-mile pipeline was built, at a cost of over $\$ 600,000$, to tie-in the 6-3 Well. In December 1999, the 6-3 Well commenced producing and produced more or less continuously until Freyberg requested on 14 February 2006 that it be shut-in. ${ }^{13}$ It was shut-in three days later.

The 6-3 Well was a relatively prolific producer. By the time of the first trial, in March 2002, it had produced $29,136 \mathrm{E}^{3} \mathrm{~m}^{3}$ of gas. By the time it was shut-in, on 17 February 2006, it had produced $41,569 \mathrm{E}^{3} \mathrm{~m}^{3}$ of gas. ${ }^{14}$

The litigation arose in the context of the receivership of Kalta, which commenced in September 2000. In the context of the receivership, it was discovered that although Apache, which was taking its gas in kind, had paid Freyberg its 25 percent share of her production royalties, Kalta, as operator of the $6-3$ Well, had failed to remit any production royalties to Freyberg. She commenced her lawsuit in November 2001, alleging that the Lease had terminated some time prior to December 1999, when the 6-3 Well had commenced production. Kalta's interest in the 6-3 Well was the most valuable asset in the receivership estate. It was for this reason that the action proceeded extremely quickly to the first trial (barely four months after issuance of the Statement of Claim) under the case management of Romaine J.

\section{THE ISSUES}

\section{A. The Onus of Proof in Lease Termination Cases}

\section{The LegAL Positions}

In the first trial, Freyberg argued that there was an absolute rule applying to all cases of alleged freehold lease terminations, such that lessees always bore the onus of establishing the validity of the lease at issue. Freyberg based this argument on two Alberta cases: 549767 Alberta Ltd. v. Teg Holdings Ltd. ${ }^{15}$ and Blair Estate Ltd. v. Altana Exploration. ${ }^{16}$ In Teg Holdings, the Court considered whether two petroleum natural gas leases had expired because the wells had not produced any natural gas after the primary term of the leases. The defendants argued that there had been no commercial production because transportation facilities were unavailable and no markets existed for the natural gas. The Court, relying

Appeal Decision, supra note 2 at para. 160; Second Trial Decision, supra note 2 at para. 11. 
upon Blair Estate, held that the onus was on the defendants to show that they fell within the clause allowing for non-production "as a result of a lack of, or an intermittent, market or lack of transportation facilities or any other cause whatsoever beyond the Lessee's reasonable control." ${ }^{17}$ In Blair Estate, the brief Memorandum of Judgment of the Alberta Court of Appeal contains no explanation of the Court's reasoning for assigning the onus of proof to the respondent lessee to demonstrate that the primary term of the lease was capable of extension because of a lack of market, or of an intermittent market, or for some other cause beyond the lessee's control. ${ }^{18}$

The defendants in the Lady Freyberg trial argued that to the contrary, there was no "special rule" whatsoever in freehold lease cases, but instead the general rule regarding the onus of proof ("he who alleges must prove his allegation") governed and in fact had been applied in previous freehold lease cases. In Paddon-Hughes Development v. Pancontinental Oil Ltd., ${ }^{19}$ the Court held that the plaintiff lessor had the onus of proving that the defendant lessee had failed to make the delay rental payments by the required anniversary dates. The lessor argued that as the lessee was essentially given an option to extend the term of the lease, it had to show that it had complied with the conditions necessary to exercise the option, being payment of delay rentals, and further, that the lessee was the one in possession of the essential information with respect to the payments.

\section{THE EVIDENCE}

By the time of the first Lady Freyberg trial, the state of the evidence was exactly what one would expect in relation to a 27-year old freehold lease. Freyberg was seeking a declaration that the Lease had terminated on the basis of two alternative allegations: first, that the defendants had failed at some time in the 27-year history of the Lease (although by trial, Freyberg had narrowed this allegation to the years 1993 and 1996, the only years in which the paper trail regarding shut-in rental payments was not clear) to make shut-in rental payments when due; or, in the alternative, that the defendants had failed to produce the 6-3 Well when there existed an economical and profitable market for the gas from the well (which Freyberg's expert testified to have been the case at any time from 1987 onwards). ${ }^{20}$

One of the practical problems was that, although Freyberg's allegations were that there had been breaches under the Lease in the 1980s and 1990s, she had only sued the present-day working interest owners, not all the parties with an interest in the Lease at the times of the alleged breaches. Notably, she had failed to sue the then current corporate successor of Voyager and Poco (Burlington Resources Canada Ltd. (Burlington)), who held the Lease until 1998. The Defendants had no basis on which to join Burlington as a third party because they had purchased their working interests from Voyager on an “as-is, where-is” basis, with no warranties as to title. 
Freyberg's approach therefore led to a not-uncommon problem in freehold lease litigation: the corporation that still employed and had control over witnesses with relevant information from the time frame in issue was not a party to the litigation. The parties to the litigation had little more than paper files. Freyberg and the defendants all had access to the exact same documentary record, via pre-trial document discovery.

Given Freyberg's allegations (failure to make shut-in rental payments and failure to produce when an economical and profitable market existed), the relevant paper records were the lease and well files for the 6-3 Well.

Different portions of Voyager's original lease file were in the possession of a number of the defendants, but the most complete version of the file had been delivered to Apache when it purchased Voyager's 25 percent working interest in 1998. While the majority of its leasehold interest had been assigned over time, Voyager (then Poco) had consistently carried out the functions of the lessee, including paying shut-in rentals. In the space of 27 years, many people had handled the file and taken part in the correspondence that made its way into the file, but the vast majority of those people could no longer be located. The people who had been involved with the Lease in the relevant time periods (prior to 1999) had been employees of either Voyager or Poco. Since Burlington, the corporate successor of Voyager and Poco, was not a party to the litigation, none of the litigants had special access to, or even any special ability to locate the relevant witnesses.

Similarly, the 6-3 Well file had been created by Gascome, Voyager's original farmee, who had drilled the 6-3 Well in 1978. Gascome was no longer in existence, and the current holder of that file was Tudor Corporation Ltd. (Tudor), the then current operator of the 6-3 Well. Tudor had purchased its interest from successors and assignees of Gascome. Again, the well file was extremely old, and Tudor had no relationship with any of the individuals who had created and maintained the file.

In essence, Freyberg and the defendants all had access to the same documents from the lease and well file of the 6-3 Well, but no privileged access to, or ability to locate witnesses who might have relevant knowledge.

With respect to the allegations regarding shut-in royalty payments, the challenge was to locate evidence that would establish the timely delivery of the shut-in rental cheques by Poco. Some of the employees at the time were still with Burlington, Poco's successor. Starting with those contacts, the defendants were able to locate a Poco manager from the relevant time period. Fortunately, she had an excellent memory of the standard procedure that was followed in mailing shut-in rental payment cheques to freehold lessors. Although this manager had not been the person who had actually mailed the cheques in 1993 and 1996, she had supervised those persons. The defendants also located at Burlington the individual who would have mailed the 1996 cheque. Although she did not recall mailing the specific cheque, she testified as to her mailing procedures at the time.

With respect to the issue of well economics, the majority of the evidence that the parties wished to tender was not dependent on what certain individuals thought, did, or said historically. Rather, the relevant evidence was given by experts who had equal access to all 
of the technical information in the 6-3 Well file, as well as the public (largely, Alberta Energy and Utilities Board (AEUB)) information regarding surrounding wells and historical natural gas prices. As is normal in litigation in Alberta, before trial, Freyberg (being the plaintiff) delivered her expert report, and the defendants then delivered a rebuttal report. Both sets of experts looked at the same historical information, and provided their opinions as to what the economics of the 6-3 Well would have been at various points in time.

\title{
3. JUSTICE ROMAINE’S DECISION
}

After hearing all the evidence and the parties’ arguments, Romaine J. noted the following about the onus of proof:

\begin{abstract}
The general rule with respect to the burden of proof is that its allocation is determined by the substantive law "upon broad reasons of expedience and fairness". It has often been stated that "a fundamental requirement of any judicial system is that the person who desires the court to take action must prove his case to its satisfaction”.... These general principles have been refined further to include the following premises:
\end{abstract}

a) That the onus is always on a person who asserts a proposition of fact that is not self evident; and

b) That where the subject matter of the allegation lies particularly within the knowledge of one of the parties, that party must prove it whether it be of an affirmative or negative character.

While specific rules relating to the onus of proof have arisen in certain classes of cases, there is no obvious [homogeneity] in cases involving oil and gas leases that justifies departure from the general rules of allocation or the creation of a single invariable rule of allocation of proof.

In most of the cases where courts have previously placed the onus of proof of validity of an oil and gas lease on the lessee, the lessee was the applicant in the action or the issue was the existence of valid pooling arrangements, a fact that usually lies particularly within the knowledge of the lessee making the allegation. ${ }^{21}$

Justice Romaine therefore rejected Freyberg's argument that Teg Holdings and Blair Estate were examples of an absolute rule that lessees must bear the onus of proving lease validity in all freehold lease cases. She observed that there was almost no discussion of the issue in those cases, nor any reasoning. Instead, Romaine J. agreed with the approach of Chrumka J. in Paddon-Hughes, wherein he specifically considered and rejected the lessor's argument that there was an absolute rule requiring the lessee to bear the onus of proving validity in all cases. ${ }^{22}$

Applying the general rule, Romaine J. found that Freyberg had the onus of proving that an economical or profitable market for gas from the 6-3 Well existed when alleged on the basis that she was the party alleging that fact. Justice Romaine noted that, with equal access to the historical documents, and given that all the parties relied largely on expert evidence 
to prove or disprove this allegation, Freyberg was in no worse situation than the defendants in proving her assertion. ${ }^{23}$ There was therefore no reason to supplant the general rule requiring Freyberg to prove her allegation.

With respect to the allegations of late mailing of shut-in rental payments, Romaine J. found that the general rule was supplanted because the defendants had control over their internal documentation and record-keeping. Therefore, it was expedient and fair to require the defendants to bear the onus of proving that they had mailed shut-in royalty payments at least 48 hours prior to the anniversary dates (this was the mailing deadline under the Lease). ${ }^{24}$ If the test under the Lease had been the date of receipt, as opposed to the date of mailing, Romaine J. may have found otherwise.

\section{THE COURT OF APPEAL’s DECISION}

The issue of onus was argued again before the Court of Appeal. Justice Ritter wrote the majority decision (Conrad J.A. concurring) and O’Leary J.A. dissented. Justice Ritter endorsed the following general rule that Romaine J. had applied:

In a civil case, the two broad principles are:

1. that the onus is on the party who asserts a proposition, usually the plaintiff.

2. that where the subject matter of the allegation lies particularly within the knowledge of one party, that party may be required to prove it. ${ }^{25}$

However, Ritter J.A. differed from Romaine J. in concluding that the effect of the general rule was to place the onus respecting the economical and profitable market issue on the Defendants:

The Lease in question has a primary term of five years. It terminates at the end of that time, or on a subsequent anniversary date if the Lease has been extended, if there is no production. Lady Freyberg relies on these provisions to assert that the Lease has terminated. To satisfy her onus she must show that the Lease is valid and that there has been no production.

If the respondents wish to rebut the argument that the Lease has terminated they can do so by asserting there has been deemed production. Clause 3 of the Lease deems that a shut-in well is producing provided the well is shut-in "as a result of a lack of an economic or profitable market." By relying on Clause 3 , the respondents are asserting that an economical and profitable market did not exist thus requiring that they bear the burden of proving so on a balance of probabilities. Such a burden is in accordance with the first principle in Snell.

First Trial Decision, supra note 2 at para. 84.

Ibid. at para. 85.

Appeal Decision, supra note 2 at para. 75, quoting Snell v. Farrell, [1990] 2 S.C.R. 311 at 321, Sopinka J. [Snell]. 
The second principle from Snell also supports the position that the respondents bear the onus of proving a lack of an economical and profitable market. The trial judge treated the question of an economic and profitable market as if it was merely a contest of experts. She held, at para. 84:

The Plaintiff, as the party wishing the court to take action to find that the lease has terminated, is in no worse situation than the Defendants in presenting to the Court expert opinion evidence that attempts to prove the assertion she makes.

This approach to the allocation of the onus ignores the second condition of Snell: where a subject matter lies particularly within the knowledge of one party, that party may bear the burden of proof on that issue.

Again, if the respondents wish to rebut the argument that the Lease has terminated they can do so by citing the deeming provision and asserting there was no economical and profitable market. In my view, a party seeking to rely on a deeming provision in a natural gas lease has an obligation to bring such evidence forward, and to explain why an economic and profitable market did not exist. The burden should not fall on Lady Freyberg to produce evidence about Voyager's business decisions and to explain why Voyager made the decisions that it did. This evidence lies particularly within the knowledge of Voyager.

The reason why the 6-3 Well was not put into production until 1999 - after the 11-34 and 11-33 Wells - is solely within the knowledge of Voyager. Voyager is also the only party aware of why the 6-3 Well was not put into production after the 11-34 Well watered out. Furthermore, the reasons that the requests for a tie-in between the 6-3 Well [and] the 11-34 Well were repeatedly refused are also solely within the knowledge of Voyager.

Therefore, while the onus of proving her case remains with Lady Freyberg, the burden of proof regarding the issue of deemed production under Clause 3 of the Lease rests with the respondents due to (a) their reliance on an exception to the lease's termination, and (b) Voyager's specialized knowledge and awareness of relevant facts not available to Lady Freyberg. Applying the onus this way is both expedient and fair. ${ }^{26}$

\section{PRACTICAL CONSIDERATIONS AND CONSEQUENCES}

For a couple of reasons, it is difficult to determine what will be the precedential value of the Appeal Decision on this point. First, the majority's reference, in the reasons cited above, to what the parties "relied on" or "asserted," simply did not accord with what the parties actually did allege and argue. In her Statement of Claim, Freyberg had not simply alleged that the Lease was invalid, but had in fact gone much further, making the positive allegation that the Lease had terminated because, at some time prior to 1999, there existed an economical and profitable market for gas from the 6-3 Well, and that the defendants' predecessors had failed to produce into that market. The defendants, in their Statements of Defence, very deliberately refrained from making any positive allegation about the lack of an economical and profitable market, but instead merely denied Freyberg's positive assertion.

In litigation, pleadings are not mere formalities. Pleadings are central to the lawsuit; they define the issues in dispute and frame the facts that need to be proven by a party. Quite simply, a party must prove the facts it has alleged in its pleadings. This is no more than the 
first "broad principle" cited by Ritter J.A. in his exposition of the general onus rule. The Alberta Court of Appeal's approach in the Appeal Decision arguably failed to take into account the actual allegations as they were pleaded by the parties.

The second interpretive difficulty with the majority's approach (as is apparent from its emphasized comments, cited above) is that it seemed to assume that Voyager, the lessee at important times in the 1980s and 1990s, was a party to the litigation, one who could lead evidence or call witnesses. That was simply not the case. Voyager was not a participant in the litigation and evidence lying "particularly within the knowledge of Voyager" was not evidence that was under the control of any of the parties to the litigation. Both Freyberg and the present-day defendants had equal access, through the discovery process, to all of Voyager's records, and had equal ability to make further investigations to try to locate individuals who had previously worked for Voyager. This observation is not intended as a criticism of the majority. Rather, it highlights the difficulty faced by appeal courts in cases such as this one, where the evidence that was entered over the course of two weeks at trial is reduced to writing and must be digested by the Alberta Court of Appeal, along with an oral hearing, without any witnesses, in fewer than two days. Inevitably, details in the factual record may be missed, overlooked, or misinterpreted.

While the majority stated that they were applying the general rule of onus and did not expressly endorse an absolute rule that the lessees bear the onus of establishing lease validity, it will be interesting to see what the effect of the Appeal Decision will be in future lease termination cases. The Appeal Decision may represent a high water mark: the defendants bore the onus to prove the existence of a profitable and economical market even though they never alleged that such a market existed, and even though they had no better access to the facts surrounding market conditions than did the plaintiff lessor.

The difficulty will surely arise again in future cases because of the business reality in the industry: fractionation of working interests and numerous divestitures, combined with "limited recourse" warranties and time-limited indemnities with respect to title issues commonly result in situations in which the original parties, whose historical conduct may have had an impact on the present rights of the litigants, are not involved in the litigation, and indeed, may no longer even exist. Often, the current interested parties have very little to go on other than old paper files and whatever additional evidence their investigations might reveal.

\section{B. DETERMining Well Economics}

\section{THE PROVISIONS OF THE LEASE}

The primary issue in the first trial and on its appeal was whether the Lease had terminated because the Defendants' predecessors had failed to produce gas from the 6-3 Well at a time when there existed an economical or profitable market for such production. The relevant clauses in the habendum and the shut-in clause of the Lease stated as follows: 
conducted thereon, or if at any time after the expiration of the primary term production of all the leased substances has ceased and further drilling or working operations are commenced within Ninety (90) days after the cessation of said production, then, in either event, this Lease shall remain in force so long as any drilling or working operations are prosecuted with no cessation of more than Ninety (90) consecutive days, and, if they result in the production of the leased substances or any of them, so long thereafter as the leased substances or any of them are produced from the said lands or the pooled lands;

PROVIDED that if drilling or working operations are interrupted or suspended as the result of any cause whatsoever beyond the Lessee's reasonable control, or, subject only to Clause 3 hereof, if any well on the said lands or the pooled lands is shut-in, suspended or otherwise not produced as the result of a lack or an intermittent or uneconomical or unprofitable market, or any cause whatsoever beyond the Lessee's reasonable control, the time of such interruption or suspension or non-production shall not be deemed a discontinuance of drilling or working operations or of production, as the case may be, anything herein elsewhere contained or implied to the contrary notwithstanding.

\section{Shut-In Gas Wells:}

If at the expiration of any year during the primary term or any extended term of this Lease there is no producing on the said lands or pooled lands but there is a well on the said lands or the pooled lands which is designated a gas well by or pursuant to any applicable statute or regulation, or by the board, governmental authority or agency having jurisdiction in that regard, and from which no leased substances are being produced as a result of the lack of an economical or profitable market, such well shall be deemed to be a producing well on the said lands under all the provisions of this Lease and the Lessee shall, on or before such anniversary date, pay to the Lessor in the same manner provided for the payment of the delay rental hereunder, as royalty, an amount equivalent to the delay rental. Like payments shall be made in a like manner on each successive anniversary date during the period that such well is deemed by virtue of this Clause to be a producing well on the said lands. ${ }^{27}$

\section{WELL ECONOMICS AS A CATEGORY OF LEASE TERMINATION}

There are many mechanisms in freehold oil and gas leases by which leases can terminate of their own accord during the secondary term. Many of these bases for termination have received judicial consideration in the historical freehold lease cases. The bases for termination include whether a pooling agreement existed at a certain time; ${ }^{28}$ whether the well was producing at a certain time; ${ }^{29}$ or whether delay rental payments had in fact been made before an anniversary date. ${ }^{30}$

Ibid. at paras. 27-28.

Gas Initiatives Venture Ltd. v. Beck (1980), 122 D.L.R. (3d) 768 (Alta. C.A.); Paddon-Hughes, supra note 19; Gibbard v. Shell Oil (1960), 26 D.L.R. (2d) 400 (Alta. S.C. (A.D.)).

Canadian Superior Oil of California, Ltd. v. Kanstrup, [1965] S.C.R. 92; Durish v. White Resource Management Ltd. (1987), 82 A.R. 66 (Q.B.), aff'd (1988), 63 Alta L.R. (2d) 265 (C.A.); Canadian Superior Oil Ltd. v. Paddon-Hughes Development Co. Ltd. (1969), 3 D.L.R. (3d) 10 (Alta. S.C. (A.D.)); Weyburn Security v. Sohio Petroleum, [1971] S.C.R. 81. 
The difference between those types of terminations and the "well economics" type termination alleged by Freyberg is profound. The former types of terminations are not matters of opinion. At any given time, any party, or a court, can accurately determine whether or not those preconditions to lease validity existed (that is, did a pooling agreement exist or not exist, or was production occurring or not occurring). In contrast, the "fact" upon which lease validity depends in a Lady Freyberg-type case - whether or not there existed an economical and profitable market for gas from a given well - is a matter of opinion on which different parties (and different judges) may have different opinions.

Therefore, in the First Trial Decision and in the Appeal Decision, a tension is apparent between the "bright line" approach to validity in the historical case law and the devilishly difficult matter of determining when an economical or profitable market for gas did or did not historically exist for a given well. As was vigorously asserted by Freyberg, many historical freehold lease cases approach the issue of freehold lease validity in the secondary term on the basis that, as soon as the precondition to lease continuance ceases to be satisfied, the freehold lease "clicks" — in other words it terminates automatically of its own terms and is not subject to revival.

While that historical approach to lease termination may make sense in the context of many "traditional" lease termination cases (depending on the state of the evidence in a given case), since the parties can relatively easily ascertain the status of the lease at any given time and act accordingly, it is antithetical to the reality of a well economics case. The difficulty, of course, is that in a well economics-type case, it is nearly impossible to contemporaneously or prospectively determine when a lease has terminated or will terminate. At the time of the termination, one may not know that the lease has terminated and arguably, one can only know for certain many years after the termination.

This practical difficulty exists because many variables that impact well economics (such as future oil and gas prices; the cost of future maintenance, re-work operations, or improvements; and perhaps most importantly, the recoverable reserves in a given reservoir) cannot be known with certainty when drilling and at the time operational decisions must be made, and are also subject to change. Similarly, production of gas from a well is only profitable if the revenue from the sales of gas produced by the well exceeded the capital and operating costs of the well. Costs (operating costs, processing costs, and many other types of costs) can change significantly over the years due to a variety of factors, including the dynamics of the labour market and changes in plant throughput. The total recovered gas and the price at which that gas was actually sold can only be known for certain after the well ceases producing. Therefore, it is only then that profitability can be known.

\section{THE EVIDENCE}

At the first trial, these business realities were admitted by Freyberg's expert witness, Keith Farries. In his cross-examination, ${ }^{31}$ he made the following admissions:

- operating decisions in the oilpatch are almost always necessarily made prospectively; 
- $\quad$ such prospective operational decisions are very subjective, because one does not know what will occur in the future. Many factors go into the making of a reasonable assessment or reasonable judgment before making such a decision;

- an operator must be reasonably satisfied about the economics of any proposed steps before such steps are undertaken or recommended and the operator has an obligation to consider whether or not the economics are appropriate;

- prudent operators make different judgment calls in making prospective economic decisions after assessing all the risks, and such decisions can be "all over the map" and still be reasonable;

- $\quad$ one never really knows, nor is 100 percent certain, what recovery of reserves will be achieved from a well until production from the well is entirely complete;

- $\quad$ in making prospective decisions as to whether an operation is economic, it is fair to consider risk factors, which include: geological risks; production risks; the risk of the well watering out early; the risk of sour gas; and economic risk related to the price volatility of natural gas;

- up to one year may elapse between a decision to tie-in a well and the commencement of production from the well, during which time the risk parameters, including the price of natural gas, could change fairly substantially;

- $\quad$ such prospective operational/economic decisions are unlike determining whether a rental payment has been made in time or drilling was started before a particular date (in which case one can tell whether or not such things have been done), and when prospectively deciding what is economic standing at a particular point in time, reasonable people can disagree; and

- utilizing actual production results and looking back retrospectively, if you run into a good well you can almost always make a case that it would have been economic earlier. $^{32}$

\section{JUSTICE ROMAINE’S DECISION}

In the first trial, Romaine J., having heard all the evidence of the parties including extensive evidence from the three expert witnesses about the realities of trying to determine well economics, came up with a solution that recognized the highly subjective nature of determining well economics: she found that it was appropriate to apply to such cases a version of the "business judgment rule":

In considering the question of whether an economic or profitable market existed at the appropriate times, these words must be given their plain, ordinary meaning in the context of the lease. The lease must be given a commercially reasonable interpretation in light of the realities of natural gas operations and markets. In that 
context, the reference to economic or profitable market must refer to the perspective of the lessee, and would therefore include reference to the cost of drilling, equipping, completing and operating the well, including costs of gathering facilities and marketing of production. To hold otherwise would lead to a situation where the lessee could be liable for failure to produce into a market that would not be economic for it, although the lessor may be entitled to production royalties.

To be fair and commercially reasonable, the status of the market must be analyzed in light of the information available to the lessee at the time. The determination must by its nature be prospective, rather than retrospective, reflecting the reality of how decisions are actually made by the lessee at the appropriate point in time. Again reflecting reality, the variables to be considered must include both objective and subjective elements, including the allocation and assignment of risk by the decision-maker at the time.

The Defendants submit that the appropriate analysis for the Court to undertake is to assess whether the prospective decision of the lessee was reasonable in light of the information it had at the time. If the lessee considered all of the material factors and acted honestly, prudently, in good faith and on reasonable grounds, the Court ought not second guess that decision.

The Plaintiff criticizes this as an inappropriate use of the rule of law referred to as the business judgment rule that applies to a Court's review of the decisions of corporate boards of directors.

Macleod, J., applied, if not the business judgment rule, a similar standard in assessing the defendants' efforts to market gas in [Canada Southern Petroleum Ltd. v. Amoco Canada Petroleum, 2001 ABQB 803, 300 A.R. 201] at paras. 265-268. He found that the decisions made by the defendants were made exercising sound business judgment, and that they did not act unreasonably. While in Canada Southern (supra), the defendants had a positive contractual obligation to develop and market oil and gas, I find it equally appropriate and consistent with a commercially reasonable interpretation of this lease to determine whether the decision of the lessee that an economic or profitable market existed at a particular point of time was reasonable given the information available at the time. This is particularly so, given that, as conceded by the Plaintiff's expert witness, prudent operators are capable of making different judgment calls in making prospective economic decisions, after assessing all of the risks. As he put it, such decisions can be "all over the map" and still be reasonable. This point was vividly illustrated in this case by a comparison of the various historical valuations of the 6-3 Well prepared internally by lessees and by their consultants.

The test thus applied is similar to the business judgment rule used by the courts in reviewing actions by boards of directors. It does not preclude a review of the expert opinions presented by the parties on the status of the market at the appropriate time in light of the information available to the lessee. If the Court finds one expert opinion more persuasive than the other, this will have implications for its view of the reasonableness of the decision of the lessee, and whether the lessee acted honestly, prudently and with adequate consideration of all material factors. ${ }^{33}$

Thus, Romaine J.'s approach recognized the difficult business realities facing lessees and further recognized that the prospective determination of well economics is a sophisticated and highly subjective matter, one upon which reasonable parties could, and often do, hold different opinions. 


\section{THE COURT OF APPEAL'S DECISION}

The majority of the Alberta Court of Appeal overturned Romaine J.'s decision on this point for two general reasons. The first was that the majority disagreed that expert evidence on the issue of well economics had been required at the first trial. It is fair to say that this ruling by the majority took even the parties by surprise as there had been no suggestion by either party that experts were not required to determine what a reasonable lessee or operator would have determined to be the historical economics of producing the 6-3 Well. The point was simply never argued. Freyberg entered her expert evidence and the defendants replied with their own.

The majority felt that expert evidence was unnecessary because "not only did a sufficient factual basis exist to decide upon the existence of an economical and profitable market for the 6-3 Well gas, the lay evidence forming this factual basis was virtually overwhelming."34 In coming to this conclusion, the majority recited a number of the basic facts about the 6-3 Well, the surrounding wells, and the desire of certain parties to produce the 6-3 Well. The majority's review of these facts was at a very high level and did not involve the type of detailed analysis of well economics and risk factors that the expert witnesses had provided.

Of more interest and impact to the industry was the majority's finding that the lay evidence of a profitable and economical market prior to 1999 was overwhelming (even when three very experienced reservoir engineers, looking at the economics as experts, had disagreed on whether the 6-3 Well was economic prior to 1999). In reaching this conclusion, the majority relied primarily on the evidence of a lay witness named Ross Anderson, who had testified during the first trial. Anderson was a junior reservoir engineering technologist with Voyager from 1986 to 1989. In that role, he had carried out reviews of Voyager's noncontracted gas reserves, including the 6-3 Well. Anderson's mandate was to recommend likely tie-in candidates to Voyager management. In this capacity, Anderson testified that he thought the 6-3 Well was a good well and he thought it could produce economically. ${ }^{35}$

There were, however, two significant qualifications to Anderson's optimistic evidence about the economics of the 6-3 Well. First, he was firmly of the view that in 1986 (the date of his area review), no gas contracts were available for 6-3 Well. Anderson was aware that Novalta Resources Ltd. (Novalta) was purchasing gas at the time under an industrial contract, but it was an area contract under which Novalta could not accept gas from Township 37, in which the 6-3 Well was located. With respect to the issue of gas markets more generally, he testified: "We had tried to obtain a second contract, [for the 6-3 Well] and there just wasn't one available at that time. There was no market [...] it was very difficult to obtain new contracts at that time as there was an over-supply of gas at that time."36

The second qualification to Anderson's evidence was that his work only involved looking at one-half of the economics equation, namely reserve estimates. He did not consider any capital costs other than well testing and completion in making his tie-in recommendations.

Transcript of Evidence at First Trial Decision, supra note 2 [archived with author]. 
For example, he frankly admitted that the other well (the 11-34 Well) he had recommended for tie-in at the same time as the 6-3 Well (and to which he had ascribed greater reserves than he did the 6-3 Well) had watered out relatively soon after it was tied in. ${ }^{37}$ Anderson was not aware if an ex post facto economic analysis of the 11-34 Well tie-in was carried out (he did not conduct one) but he surmised that Voyager probably did not recover the capital it had spent on that well. He frankly admitted that if he had known how the 11-34 Well would turn out as a producer, he would not have recommended that it be tied-in.

Without evaluating the "cost" side of economics, it is difficult if not impossible to form an overall opinion about profitability. Similarly, without a market, there can be no economical or profitable market.

\section{Justice Romaine having heard Anderson’s testimony, noted the following:}

Mr. Anderson testified that his understanding was that the 6-3 Well was not put on production at this time because it did not have a market and could not be tied in. His memo was passed on to his supervisor at Voyager. He recalled discussions with Novalta Resources Ltd., the then owner and operator of the Hamilton Lake Gas Gathering System with respect to the tie-in of the 6-3 Well, during which he became aware that Novalta could not take gas from the 6-3 Well because Novalta's industrial sales contract did not allow it to take gas north of township 36 .

Mr. Anderson testified that, in his opinion, the 6-3 Well looked to be a better well than the 11-34 Well because it was structurally higher and had less risk of water inflow. He thought at the time it should be tied-in if a purchase contract could be obtained and the economics of tie-in could be worked out. He pointed out that it was very difficult to obtain gas purchase contracts at this time as there was an over-supply of gas. Mr. Anderson rejected the suggestion that Voyager chose to tie-in the 11-34 Well instead of the 6-3 Well because it was more profitable for Voyager to do so given its larger interest in the 11-34 Well, stating that this was not Voyager's intention.

Mr. Anderson prepared an internal memo at Voyager dated October 4, 1988 recommending that Voyager execute the Authorities for Expenditure to complete and test the wells suggested by Tudor in which Voyager had an interest, including the 6-3 Well. However, he was not aware of whether his recommendation had been accepted, and no Authorities for Expenditure executed by Voyager were produced.

The Plaintiff places great reliance on the testimony of Mr. Anderson with respect to his opinion that the 6-3 Well would have been economic and profitable to produce. Apart from the fact that Mr. Anderson's opinion was merely that, a subjective, prospective opinion among other, his evidence is not as unequivocal as has been characterized by the Plaintiff, and must be qualified by its context and in its entirety. Mr. Anderson's evidence in this respect is merely part of the entire picture of development history, and not a determining factor. $^{38}$ 
In contrast, the majority of the Court of Appeal placed heavy reliance on Anderson's evidence:

The trial judge dismissed Anderson's testimony as being "a subjective, prospective opinion among other[s]...not as unequivocal as has been characterized by the plaintiff," and one which had to be "qualified by its context and in its entirety".... This critique of Anderson's evidence does not withstand review. Anderson, who was Voyager's reservoir technologist during the time relevant to this appeal, testified about Voyager's actions relating to the 6-3 Well. He was the only employee of Voyager to testify. No other witnesses were familiar with the positions or views of Voyager in relation to the 6-3 Well. He was unequivocal in his belief that, with a production contract, the 11-34 Well was economic and profitable to produce.

If the respondents wished to contest Anderson's assessment of [the] 6-3 Well, they had the opportunity to contradict his testimony with the evidence of rebuttal witnesses who were present at the relevant time. They chose not to do so. As a result, Anderson's evidence reflected Voyager's opinion about the prevailing market conditions. The trial judge's failure to draw this inference, coupled with her rejection of Anderson's evidence, was not reasonable and caused her to err in her overall appreciation of his evidence. ${ }^{39}$

In essence, what the majority of the Alberta Court of Appeal concluded is that Anderson, a junior reservoir technologist who was not tasked with determining whether or not he or his employer Voyager thought it was economical to produce gas from the 6-3 Well, could be taken to speak for the company on that issue. His opinion was viewed in isolation from the business decision-making context and the realities of the oil and gas company.

\section{PRACTICAL CONSIDERATIONS AND CONSEQUENCES}

A number of concerns have been expressed about this conclusion from the perspective of the industry. First, anyone who is familiar with the manner in which most oil and gas companies operate will realize that an engineer in the position of someone like Anderson is usually a strong advocate of his or her proposed projects. The mandate of such an employee is usually to carry out an analytical review in order to identify potential development prospects for recommendation to management. Inevitably, such people become advocates of those projects or wells that they have studied in detail and in which they believe. However, that is also the reason why projects, in most companies, must be approved by higher management levels before they proceed. At those higher levels, executives with greater responsibility and greater information (for example, with respect to issues such as costs and budgets) make executive decisions about whether to proceed with certain projects. As was clear from his evidence, someone like Anderson is tasked only with looking at part of the picture. Given this business reality, it is troublesome that the evidence of a low-level employee, tasked with only considering one aspect of a project, may be taken to be the opinion of the company as a whole.

It is also not realistic, from a business reality perspective, to state that additional witnesses could have been called to rebut the evidence of someone like Anderson. As stated previously, the defendants had no control over, nor special access to, former employees of Voyager. 
They located Anderson and called his evidence because it was relevant and helpful in allowing the Court to understand the events that were occurring in the late 1980s. There was no intention to suppress or not call additional evidence from other witnesses. The defendants attempted to, but could not, locate any of the higher-level managers to whom Anderson reported. Had this been a case in which the lessee was a participant in the lawsuit, one who had the ability to call or not call employees as witnesses, the majority of the Court of Appeal's approach would, perhaps, make sense. However, those were not the facts, nor the business reality, of the Lady Freyberg case.

In the fast-paced environment of day-to-day oil and gas business operations, many decisions are made (with respect to capital expenditures, acquisitions and divestitures, operating costs, reworks, and maintenance, to name just a few examples) in reliance on lessthan-perfect economic indicators, and divergent opinions will therefore exist. What does it mean for the oil and gas industry and corporations as a whole, if a court, with the benefit of hindsight, can isolate and focus on one employee's opinion (removed from the decisionmaking process), as the determinant of what corporate decision should have been made? Might this be used to erode the long-standing business judgment rule? If one employee outside the decision-making process evidences a different opinion from the corporation's directors, will such directors no longer be insulated from liability? All of these problems are compounded even further if a current interest owner can be fixed with the business decisions of a predecessor in interest, but has no access to witnesses or evidence that might explain the predecessor's decision.

In addition to the troubling evidential and practical aspects of how these cases may proceed, there is also an important policy consideration: the more the analysis moves away from a reasonable business judgment-type approach and toward a more simplistic analysis of well economics, the more likely it is that this type of litigation will be encouraged.

Given that working interest owners never know what production will be achieved from a given well until all production from the well has in fact occurred, a working interest owner is only able to conclusively determine whether tying-in a well was economical or profitable (and therefore whether the market into which the well produced was economical or profitable) retrospectively, with the benefit of hindsight. No accurate determination regarding the profitability of a market can truly be made before this time, although assessments can be made through time, with increasing degrees of certainty, as production and revenues accrue.

When combined with the traditional "bright line" jurisprudential approach to freehold lease termination, it is easy to see how these business realities could lead to some potentially profound consequences. If the proper legal test for well economics-based terminations is a simple "black and white" test, one could argue that every well that ends up achieving greater production and revenue than the lessee forecasted at the time the well was put on production should have been put on production sooner. In other words, an economical or profitable market for the gas from that well existed at a time prior to when the well was actually put on production (whether the profitable or economical market existed days or years before the well was tied in). The lessor could therefore argue after the fact that the lease terminated prior to production and sue for a declaration that the lease had "clicked" prior to the well being tied-in. 
In addition to the potential encouragement of more litigation, the more "bright line" approach to these cases will make it increasingly difficult for counsel to give advice and for in-house counsel and oil and gas companies to manage their businesses in accordance with such advice. It is unlikely that the manner in which decisions about proceeding with projects are made will or can change. Companies owe duties to shareholders, and business decisions about economics have to be made in the context of imperfect information, but in good faith and in a reasonable fashion. If the manner in which those business decisions are subsequently judged continues to move away from a business judgment-based approach, industry participants may be increasingly exposed to risk. It will never be practical to conduct an expensive and time-consuming full engineering review of every well every time a decision has to be made about that well. It will also not be practical to take reservoir engineers out of the picture, or to require that the only analysis of every decision on every well be made only at the very highest level of management, considering all available information. Business efficiency would be utterly destroyed. This would represent a step backwards in the evolution of the law, resulting in less certainty from a business perspective.

\section{Measuring Damages in Lease Termination Cases}

The main issue in dispute in the second trial was the quantification of Freyberg's damages. Recall that, as a result of the Supreme Court of Canada's decision to deny leave in November 2005, it had been conclusively determined that the Lease had terminated at some undetermined time prior to December 1999. Since December 1999, the 6-3 Well had produced (more or less) continuously until February 2006. The defendants had paid to Freyberg some, but not all, of the royalties to which she would have been entitled under the Lease.

\section{THE LAW}

The question arose as to whether compensation should focus on the plaintiff's loss (compensatory damages), as the defendants asserted, or on the defendants' profits (restitutionary damages), as Freyberg claimed. This brought to the forefront the clear tension between the long-standing case law (awarding damages for conversion and trespass under absolute rules of harsh or mild damages) and the recent revitalization of the royalty model of damages (recognizing the business realities of natural resource exploitation). Despite a reasonably large body of nineteenth-century English case law dealing mostly with the wrongful removal of coal from under a plaintiff's property, there were very few reported cases in Canada dealing with the appropriate measure of damages in a freehold petroleum and natural gas lease-termination situation. The Canadian jurisprudence primarily addressed forestry or mining.

The only recent Canadian precedent in the oil and gas context was the decision of the Saskatchewan Court of Appeal in Montreal Trust v. Williston Wildcatters Corp. ${ }^{40}$ Boiled 
down to its bare essentials, the second trial was really about whether the Court would apply the Williston approach to the facts of the Lady Freyberg case.

The Saskatchewan Court of Appeal in Williston comprehensively reviewed the existing case law dealing with damages in the case of the wrongful taking of minerals. The Court explained the spectrum of damages in the case law as follows:

The main objective in awarding a plaintiff damages is to put that plaintiff in the same position it would have been in had the wrong not occurred. This principle derives from equity and has as its goal doing justice and equity between all the parties on the facts.... In the context of natural resources that are taken from land the courts have developed a method of determining the value of such natural resources. In the case of trespass, there is a punitive element to the damages which will be awarded that is reflected in the "harsher" rule as described in [Martin v. Porter]. This rule is designed to deter wilful trespass. On the other hand, where the trespass is not tainted by fraud or bad faith, the punitive element is removed, and the trespasser "breaks even" with the plaintiff recovering what they would have had they harvested/extracted the resource and put it to sale. This prevents the plaintiff from receiving a windfall where it is not warranted.... There is a further refinement that where the plaintiff is a person who could not or would not extract or harvest the resource himself or itself, but would have procured a third party to do so, the damages awarded by the courts reflect only the royalty the plaintiff would have received for the exploitation of the resource. The reason for this is that if the plaintiff receives more it will receive what it could never have obtained. Although such refinement does give the trespasser the profit it would have received had they acted lawfully, such result is justified by reason of the lack of bad faith or the mistaken belief that they were acting lawfully, and it is preferable to giving the plaintiff a windfall profit in such circumstances. Arguments that suggest that this will encourage the trespassers to be careless as to whether they act legally or not should be instantly quelled: a trespasser who does so is almost certain to fall under the harsher head of damage due to their negligence or bad faith, and thus this option of damages is not even open to the court. ${ }^{41}$

The defendants in the Lady Freyberg case argued that the royalty “refinement” should apply in this case. Further elaborating on that refinement, the Saskatchewan Court of Appeal stated:

The rule is generally that the damages are the value of the thing taken minus costs for severance, production and marketing, with no allowance for profit to the trespasser. However, there is an exception to this rule. Where it is proven that the claimant could not or would not have taken the resource or other valuable thing and put it in a saleable state, the best evidence of the loss to the claimant is the royalty that the claimant would have received had there been an agreement to do what was done ([Livingstone v. Rawyards Coal Company]). This is included within the "milder" rule, and is a reflection of the overall goal of damages in this context: to put the plaintiff in the position he would have been in had the wrong not occurred.

If one compares Livingstone with the case at bar, it is clear that the trial judge found the appellants could not and would not have produced oil from the land but would have engaged a third party to do it. To order the respondents to pay damages in the amount requested by the appellant would result in a large windfall profit to the appellant akin to the "singular stroke of luck" in Livingstone. The trial judge balanced all the equities 
and found that the value of the money that the appellant could realize for the leased substances in situ was the royalty, the best royalty attainable at the time plus a bonus. In my opinion, he was correct in so doing. ${ }^{42}$

Some of the Saskatchewan Court of Appeal's rationale for the application of a "royalty" approach to the damages in that case, which the Defendants urged was also in place in the Lady Freyberg case, was as follows:

(a) The [plaintiff] could not have drilled the well itself and the only way it could have received revenue from the property was to lease it to a third party;

(c) even after an issue arose concerning the validity of the lease, the unitholders wanted production to continue with [the current lease] in place [or with the disputed lease in place].

(e) The [plaintiff] at no time requested the respondents vacate the property. They were content to have production continue and to receive royalties.

(f) There was no bad faith or mala fides on the part of [the defendant]. All parties were operating under a mutual mistake as to their respective rights. ${ }^{43}$

\section{The PARTIEs’ POSITION}

Given that the Saskatchewan Court of Appeal's decision in Williston was rendered in September 2004, and the Supreme Court of Canada denied leave in November 2005, all the parties in the Lady Freyberg case were focused on the Williston approach. Freyberg argued strenuously that the "mild" or "harsh" rule was the invariable rule in Canadian oil and gas cases, and that the "royalty" approach in Williston was an aberration that had no place in the law of freehold leases in Canada. The defendants argued, equally vigorously, that the royalty approach to damages in Williston was not an aberration at all, and in fact was no more than an application of the general rule governing all damages awards: the general rule that a plaintiff should be placed in the position that he or she would have been in "but for" the tort. In contrast to the mild and harsh rules, the defendants argued, the royalty approach accounts for the business realities in the oil and gas industry, and consequently, does not overcompensate the plaintiff.

Freyberg had amended her Statement of Claim in the spring of 2006, and had attempted to plead herself "out of” the royalty model of damages. Her amended pleading contained the following allegation: 
At all times after the point in time when she first understood that the Lease had terminated, the Plaintiff has wanted to, herself, acting through a contract operator, operate the Well for the continued production of natural gas therefrom. The Oil Company Defendants have, however, without colour of right, refused to allow her to produce her natural gas through the Well. ${ }^{44}$

Thus, Freyberg was alleging, in the context of Williston that she was not the type of plaintiff who "would not or could not" extract her own hydrocarbons. Of course, such a broad pleading provided the defendants with the ability to examine Freyberg extensively in two areas: her historical understanding of when "the Lease had terminated" and her desire to herself, "through a contract operator," operate the $6-3$ Well. ${ }^{45}$ Freyberg was compelled to produce documents not usually encountered in oil and gas cases: her tax returns and her brokerage statements, all to support her contention that she possessed the financial ability to "run her own show." 46 Additionally, by compulsion of a Case Management Order and an Order granted by Kent J. in the middle of the second trial, Freyberg was required to produce extensive records to the defendants disclosing the advice that she sought and received, from counsel and other consultants, as to the termination of the Lease. These were records that would normally be privileged and not producible.

\section{THE EVIDENCE}

In her examination for discovery and her cross-examination at the second trial, it became clear that Freyberg was not a sophisticated oil and gas investor and in fact had quite a low risk tolerance as an investor. Among other things, she testified that

- $\quad$ her investment philosophy was to "increase conservatively";

- she did not wish to take risks on speculative investments;

- $\quad$ she had never invested in a natural resource exploration venture;

- $\quad$ she had not invested in anything riskier than stocks and bonds;

- $\quad$ she did not "like risk of any kind"; and

- $\quad$ she would never pledge either of her two major assets, being her hereditary country home in Surrey, England, or her stock and bond portfolio, as collateral to obtain funds. ${ }^{47}$

In support of her allegation that she intended to operate the 6-3 Well for herself, she gave evidence that in November 2006 she incorporated an Alberta corporation, wholly owned by her, called Surrey Gas Ltd. (Surrey Gas). Surrey Gas had no assets other than an option to 
lease the Lands that had been granted to it by her. In cross-examination, Freyberg admitted the following:

(a) She did not entirely personally understand the risks involved in Surrey Gas operating a gas well (although she understood that there were heavy risks involved in anything to do with drilling gas wells);

(b) no one had explained to her the exact risks that would be involved in a drilling operation or completing a gas well;

(c) she had heard about a well watering-out, but had not had specific discussions about this risk;

(d) she did not know all of the details of the costs that would have to be expended by Surrey Gas to carry out operations with respect to her gas rights;

(e) she did not have an understanding of the potential liabilities that Surrey Gas might incur in carrying on operations as an operator;

(f) she did not know the risks and difficulties that would be involved in carrying out negotiations for transportation agreements for the gas;

(g) she was unaware of the potential tax risks and tax liabilities for Surrey Gas;

(h) she was unfamiliar with insurance requirements for Surrey Gas;

(i) she was unaware of what workers' compensation requirements might apply to Surrey Gas;

(j) she knew nothing about the environmental risks and liabilities that Surrey Gas might incur by becoming an operator;

(k) she had no understanding that, as one of the directors of Surrey, she might be personally liable for environmental risks;

(l) no business plan existed for Surrey Gas;

(m) there was no projected rate of return for Surrey Gas’ intended business;

(n) she did not know what the total capital requirements were for Surrey Gas' intended business;

(o) she did not know if any analysis of the costs and rate of return had been conducted with respect to Surrey Gas’ intended business; and 
(p) she did not know if Surrey Gas had a plan in place to deal with its potential tax obligations. $^{48}$

Based on this evidence, the defendants argued that Freyberg's incorporation of a company to operate her gas rights was nothing more than a litigation strategy and did not truly alter the fact that she was exactly the type of person (a foreign resident with low risk tolerance, sparse business experience, and virtually no understanding of the oil and gas business) who would not and could not produce her own petroleum or natural gas well.

\section{JUSTICE KENT’S DECISION}

Justice Kent carefully considered Williston and the cases that preceded it, and determined that the compensatory model was the correct one on the facts before her:

In my view, the appropriate approach to damages in this case is the compensatory approach. There is no question that the Oil Company Defendants took Lady Freyberg's gas and have therefore committed the tort of conversion. To make an award that focuses on the Oil Company Defendants' conduct requires that I find conduct that was sufficiently reprehensible to ignore the possibility that Lady Freyberg would be overcompensated. I can find no such conduct.... Accordingly, the appropriate measure of damages must be based on a compensatory model. What that is will differ from case to case. The fundamental rule is that the quantum of damages should be in an amount to put the injured party in the same position, or as near to the same position as possible, as she would have been in, but for the tort. In some cases, where there has been conversion of minerals, that will mean that the injured party will receive the value of the minerals removed minus the costs of removing the minerals, resulting in an award equivalent to the mild rule, of damages were being awarded on a restitutionary basis. In other cases, if it is shown that the owner could not have removed the minerals on her own, the amount will be calculated in a different manner such as royalty and bonus payment. $^{49}$

Thus, Kent J. did not hold that the compensatory damages model would be applicable in all cases of terminated freehold oil and gas leases. Rather, she concluded that, on the facts of the case before her, the royalty approach was the correct one. In coming to this conclusion, she relied on the fact that none of the defendants had acted in a reprehensible manner so as to require restitution rather than compensation. She also relied on the facts of Freyberg's circumstances:

The next issue is whether or not Lady Freyberg would have produced this well on her own. Above I found that Lady Freyberg had not told the truth about when she formed the intention to produce the gas herself rather than enter into some kind of lease arrangement with an experienced gas producer. In fact, her evidence is irrelevant to the issue. There are too many institutional barriers to Lady Freyberg operating this well herself either personally or through a corporation, even with an experienced contract operator to do the work. First there is NV Resources. They would not agree to any arrangement whereby Lady Freyberg produced the gas. Second, Lady Freyberg does not have the surface lease or the well licence which raises the possibility that she would need to drill a new well. I acknowledge that the EUB is available to regulate disputes in such circumstances but there is uncertainty about the outcome of any application to the Board. 
Accordingly, to put Lady Freyberg into the position she would have been had the gas not been produced by the defendants, I need to determine what kind of lease arrangement Lady Freyberg would have had with the Oil Company Defendants. ${ }^{50}$

Justice Kent found that there was insufficient evidence for her to decide what hypothetical lease negotiation would have taken place between Freyberg and the defendants. The parties to the Lady Freyberg case settled the litigation in the fall of 2007, without tendering further evidence and without having the Court determine the exact hypothetical royalty to which Freyberg would have been entitled. The case was settled on a confidential basis and the quantum of settlement will not constitute a precedent for others (among other things, the case was settled for an all-inclusive sum that included, without any apportionment, damages, interest, and costs).

As can be seen from the excerpted portions of Kent J.'s decision set out above, she did not decide that the royalty model of damages is the law of Alberta in all freehold lease termination cases. In fact, she decided quite the contrary. Not only did Kent J. reject Freyberg's argument that the restitutionary approach was the established rule in Canada, she made it very clear that the appropriate measure of damages is a matter of equity, to be determined on the facts of the specific case before the court.

In fact, Kent J. was not the first justice in Alberta to award compensatory-based damages in a case of wrongful extraction of oil and gas. In Xerex Exploration Ltd. v. Petro-Canada, ${ }^{51}$ LoVecchio J. awarded damages on a compensatory model, based on what the plaintiff would have done. Xerex had a deep rights licence in a parcel of land and Petro-Canada had the shallow rights to the same land. Justice LoVecchio concluded that Petro-Canada had committed a trespass and conversion by drilling more than 15 metres into the deep rights owned by Xerex. He also found Petro-Canada liable for misrepresentation.

In considering what damages ought to be awarded to Xerex, LoVecchio J. focused on the loss to Xerex, rather than on the profit of Petro-Canada. ${ }^{52}$ Justice LoVecchio considered what Xerex would have done with the deep rights, absent the wrongs committed by Petro-Canada. Although the principal of Xerex was a "highly experienced oilman," LoVecchio J. found that it was unlikely that Xerex would have operated the well itself. ${ }^{53}$ The Court held that Xerex, contrary to its submissions, would not have taken over the well and developed it on its own. The Court assessed the information available to Xerex at the time, without the advantage of hindsight, the fact that Xerex had never drilled a "posthole," that its exploration expenditures were fairly minimal, that it had never obtained a licence to drill or operate a well in Alberta for its own account, and that its past history demonstrated that it would likely have sought some form of arrangement involving a direct participation by itself and some participation by others. ${ }^{54}$ Based on all of these factors, the Court found that Xerex would not have developed the well itself, but rather would have bargained for a more lucrative deal. Justice LoVecchio noted that Xerex had two remaining options: to negotiate a higher royalty from

Ibid. at para. 138.

2003 ABQB 746, 343 A.R. 347, aff'd 2005 ABCA 224, 367 A.R. 201.

Ibid. at para. 130 .

Ibid. at para. 146.

Ibid. at paras. 151-53. 
Petro-Canada or to negotiate participation rights in the nature of a farmout. ${ }^{55}$ Justice LoVecchio found that the evidence supported the latter option, and concluded that "Xerex would have negotiated a farmout [deal] with the participation rate being 50/50." "56 Thus, LoVecchio J. awarded damages for past and future loss of revenue, on the basis that Xerex was entitled to 50 percent of this revenue.

\section{PRACTICAL CONSIDERATIONS AND CONSEQUENCES}

One of the most interesting issues that comes out of the Williston and Lady Freyberg decisions is the extent to which freehold mineral lessors will be able to, in the right case and on the right facts, receive restitutionary rather than compensatory damages. In her closing argument, Freyberg argued that there were sound policy reasons to award restitutionary damages, in the interest of deterrence. Justice Kent and the Court in the Saskatchewan Court of Appeal in Williston dealt with that concern by restricting the compensatory approach to cases where the defendants did not act in bad faith. Both courts were satisfied that this limitation on the application of the compensatory/royalty model would provide sufficient deterrence to parties seeking to take advantage of lessors.

Another interesting question that may arise in future cases is whether a given lessor, particularly an individual, will ever be in a position to operate its own well, given the significant barriers to entry in the industry. As noted, rather than focusing on Freyberg's evidence about her intention and capability to operate her own well, Kent J. chose instead to focus on the structural impediments to Freyberg operating her own well. She concluded that those structural impediments in and of themselves meant that Freyberg would not or could not have extracted her own minerals, and instead would have had to lease her gas rights to enjoy them. The structural impediments that Kent J. cited were that Freyberg did not own the wellbore or surface equipment (the defendants did); she did not hold a surface lease or well licence; the option of drilling her own well and pursuing a forced pooling application before the AEUB was fraught with uncertainty; and NV Resources (the 1/3 freehold owner of the Lands) would not consent to any arrangement under which Freyberg operated a well on the Lands.

The defendants called expert evidence from the President of the Canadian Association of Petroleum Landmen (CAPL), Ian Clark. Clark testified as to the numerous and relatively complicated steps, obstacles, and issues that an individual freehold lessor would have to come to terms with if he or she truly wished to be in the position of a working interest owner, as opposed to a mere lessor:

(1) $[\mathrm{M}]$ ost oil and gas companies with whom an individual freehold owner will be required to deal strongly prefer to do business with non-industry individual mineral owners only in a lessor/lessee relationship, since most non-industry individual mineral owners are not well-versed in energy industry operating practices, the risks of significant capital investments for non-guaranteed profitable results, and the complexity of energy industry regulations and contracts; 
(2) the individual freehold owner would have to negotiate, review and become party to a variety of relatively sophisticated industry agreements, such as Farmout Agreements or Joint Operating Agreements (including CAPL Operating Procedures, CAPL Farmout Procedures and PASC Accounting Procedures), Construction, Ownership and Operation Agreements for any jointly-owned facilities, Gas Purchase Contracts for any short-term or long-term gas sales arrangements, and agreements with pipeline companies for pipeline space for transportation of natural gas;

(3) additionally, if the individual freehold owner was the 100 percent owner of the mineral title and wanted to "go it alone," the requirements would increase substantially and the owner would have to:

- acquire surface lease(s) from the surface rights owner(s) and other required surface access documents (e.g. road-use agreements, crossing agreements, etc.);

- obtain the necessary approvals to become a licensed operator in Alberta;

- obtain appropriate operator's insurance for liability and environmental risks;

- obtain a drilling licence and other pre-drilling regulatory approvals;

- recruit and negotiate contracts with companies who would provide a suitable drilling rig, wellsite supervisors and other services required to drill, log, test, case, complete, equip and tie-in the well;

- negotiate arrangements with existing pipeline companies to construct pipelines to the well or build a pipeline from the well to the nearest connection point;

- negotiate access to third-party compression and processing facilities, as required; and

- negotiate marketing agreement(s) with suitable gas marketing companies;

(4) individual freehold owners' inexperience with these types of conventional energy industry agreements could significantly slow down the operations of industry partners and affect their bottom line, which is one of the primary reasons why they simply prefer not to do business with individual freehold owners as working interest partners; and

(5) individual freehold owners would be exposed to potentially significant capital costs, including drilling, logging, testing, casing, completion, equipping, tying-in, workovers, re-completion and other standard costs. In Mr. Clark’s experience, non-industry individual investors are typically reluctant to pay any additional 
costs once a well has started production, and do not generally understand the ongoing obligations of well ownership. ${ }^{57}$

Both Freyberg's expert, Farries, and the defendants' expert witness, Clark, testified that, in their long and varied careers in the oil and gas industry in Canada, they had never encountered a case in which a foreign resident with a fractional interest in a single well had operated or contract-operated her own well.

In light of the structural impediments to entering the oil and gas industry, it seems extremely unlikely, if not impossible, that an individual lessor will ever be able to establish that he or she could develop his or her mineral interest on his or her own.

Interestingly, the issue of how and when industry participants determine well economics, in the context of operational decisions, arose again in the second Lady Freyberg trial. Freyberg advanced the position that the defendants had been negligent or had acted in bad faith when they carried out operations on the 6-3 Well in 1998 and tied it in thereafter, because they should have realized that the Lease had already terminated. She alleged that the defendants should have obtained a title opinion as to the Lease's validity prior to drilling. To that end, Freyberg's counsel cross-examined Apache's corporate officer with respect to the due diligence Apache exercised when it purchased its 25 percent working interest in 1998.

Apache's asset purchase was not atypical of hundreds, if not thousands, of other shut-in gas well purchases in Western Canada. In the purchase from Poco, Apache had acquired interests in a number of processing plants and more than 100 gas wells. Around 2/3 of the gas wells were on freehold lands, and more than 30 were shut-in at the time of the acquisition, including the 6-3 Well. The total purchase price was $\$ 2,825,000$. None of that price was attributable to the shut-in gas wells. On the contrary, pursuant to Apache's corporate policy at the time, shut-in gas wells were each assigned a $\$ 25,000$ liability (on account of anticipated abandonment costs). In the view of the former Apache engineers who were interviewed in preparation for the case, it was common practice in the industry for vendors to require purchasers to take the shut-in gas wells in an area, along with the valuable producing wells, in a purchase and sale transaction of this nature. ${ }^{58}$

Apache's due diligence process for the shut-in freehold wells (which the President of CAPL testified was industry standard at the time) was simply to verify the chain of title and then review the lease file to ensure that all shut-in royalty payments had been made. This process was carried out with respect to the 6-3 Well. As can be expected in a $\$ 2,825,000$ transaction involving over 100 wells, Apache did not conduct, for the 6-3 Well, or any other well for that matter, any type of engineering evaluation to determine whether an economical or profitable market for gas existed at some time prior to Apache's acquisition, alone, or as part of any title opinion. 
Although Freyberg alleged that the defendants were negligent in not obtaining a title opinion as to the validity of the Lease, this issue was not fully argued, nor was it decided by Kent J. Some of the historical case law supports awards of "harsh" damages — being the value of the natural resource minus only post-severance costs (rather than the royalty approach to damages) — for conduct that is found to be sufficiently negligent or reprehensible. In Sheshaht Band of Indians v. MacMillan Bloedel Ltd. ${ }^{59}$ the Court considered what behaviour warrants harsh damages. There, the defendant cut timber on the plaintiff's land without following the standard procedure of obtaining survey notes to locate the property line before conducting logging operations. The Court found that this failure to follow standard procedure was sufficiently negligent to attract harsh damages.

The issue arises as to what constitutes negligence, and conversely, what is the requisite standard of practice in the context of an oil and gas lease. What is sufficient due diligence by an oil and gas corporation when purchasing properties or conducting its ongoing operations? For example, does the corporation need to assess whether the lease might have terminated prior to drilling, and is it sufficient to merely check for timely shut-in royalty payments, or does it have to go beyond that and undertake a lengthy and costly engineering review to determine whether there was a profitable and economical market?

It is submitted that Kent J.'s decision on the proper approach to damages was not only the correct decision on the facts of the Lady Freyberg case, but was also substantially in accordance with business realities in the oil and gas industry. However, it is clear that Lady Freyberg was a case with relatively "easy" facts in this regard. Freyberg, as a foreign individual with little business experience or acumen, almost no risk tolerance, and virtually no knowledge of the oil and gas industry, was not the type of person who could ever realistically be a candidate to operate her own gas well. The reality of the case is that she would have developed her interest in the Lands by leasing them to an experienced oil and gas industry participant. It will be interesting to see how future courts apply the Lady Freyberg precedent in cases where the facts are more difficult, and where the lessor is not so obviously a person who would never have "run their own show."

\section{LEAVE AND LICENCE}

\section{THE LAW}

The other issue that was somewhat novel in the freehold lease context and that played a very prominent role in the second Lady Freyberg trial was the issue of "leave and licence." Leave and licence is essentially an alternative term for consent, a tort defence that is of great antiquity and that is well-established in tort law. ${ }^{60}$ However, despite this long history, there were few examples of the leave and licence defence being applied in Canadian oil and gas cases prior to Williston. 
The effect of a successful leave and licence defence is profound: for the period in which leave and licence to produce a petroleum or natural gas well is found to have existed, there can be no finding of trespass, even in the absence of a valid lease. A finding of leave and licence decreases the damages that will be awarded. During the time period for which leave and licence is held to have existed, a freehold owner is only entitled to damages based on the royalty that it would have been paid under the terminated lease, as though the lease still exists. This represents an interesting contrast to some of the old case law holding, that once a freehold lease "clicks,” it cannot be revived. Leave and licence appears to provide a "back door" method by which the lease terms may continue to govern.

In Williston, the Saskatchewan Court of Appeal enunciated the core principles of the leave and licence defence. The Court first clarified that leave and licence need not be given expressly, rather "it can be implied: (a) through conduct; (b) through acquiescence; or (3) a combination of all three.” 61 The Court also made it clear that courts must undertake a broad factual inquiry to determine whether leave and licence was given, since "[a]ll relevant circumstances must [be] examined to determine whether the conduct of the plaintiff amounts to leave and licence on the facts of the case." ${ }^{, 2}$

After comprehensively reviewing the leave and licence jurisprudence, the Saskatchewan Court of Appeal identified the following factors which may be indicative that leave and licence has been granted in a particular case:

i) tacit consent, implied from conduct;

ii) an agreement or understanding, or the anticipation of an agreement, for the defendant to be on the land;

iii) trespass over a long period of time, years before litigation commenced;

iv) the plaintiff had knowledge of the trespass;

v) the plaintiff had knowledge of its own legal rights and did not make a mistake as to its legal rights;

vi) the plaintiff had no reason to believe the trespasser thought he had a legal right to be on the land;

vii) the defendant did not ignore the plaintiff; and

viii) lack of defiance or contempt in defendant's conduct. ${ }^{63}$

The Court of Appeal in Williston referred to the factors listed above as "necessary" indicia. However, it is likely not necessary to prove all the factors to establish leave and licence, as is evident from Williston itself, where not all of the factors were present but leave and licence was nonetheless found to have existed. 
For the purpose of further analysis, these eight "indicia” as identified by the Saskatchewan Court of Appeal can be subdivided into three broad categories: (1) factors going to the plaintiff's knowledge; (2) factors going to the plaintiff's conduct (express or implied); and (3) factors going to the defendant's conduct.

\section{JUSTICE KENT’S DECISION}

\section{a. The Plaintiff's Knowledge}

The issue of the plaintiff's knowledge is central to the issue of leave and licence. For a plaintiff to meaningfully grant consent to an ostensible trespass, it obviously makes sense that the plaintiff must have some knowledge that the conduct he or she is consenting to constitutes a trespass. The questions that received a great deal of attention in the second trial in Lady Freyberg were what type of knowledge, and how much knowledge, the plaintiff needs to validly grant leave and licence.

The Saskatchewan Court of Appeal in Williston had laid out some guidelines:

The law only requires that a plaintiff, when granting explicit consent or when acquiescing to a trespasser, knows its own proprietary and legal rights. In the present case, the appellant clearly knew its proprietary and legal rights. Indeed, it fully exercised the latter. ${ }^{64}$

The Saskatchewan Court of Appeal in Williston also dealt in some detail with the issue of how certain the plaintiff's knowledge must be before he or she can grant leave and licence (finding that the trial justice below had erroneously required a very high level of certainty):

\footnotetext{
However, in my opinion, the concern expressed by the Chief Justice over the appellant's inability to "know" its position is a red herring. The result of such a position is that there could never be leave and licence where there was a pre-existing agreement that underpinned the subsequent trespass. Further, no party in any context is ever sure of their position until it is determined by a court of law. Until that time, it is a "position" based upon their belief or founded upon legal advice. At best all that could be said is that where there is no underlying legal agreement between the parties, the plaintiff is more certain that a trespass will be found and that they are not likely exposing themselves to liability for damages in asking the ostensible trespasser to leave or cease and desist. It is unlikely, for example, that the plaintiffs in [de Wurstemberger v. Royalite Oil Co. or R. v. C.P.R.] were in any better position to assess the legal outcome of their claims than the appellant was in the present case. The possibility of pecuniary exposure is not enough to oust a finding of leave and licence on the present facts. ${ }^{65}$
}

It will be recognized immediately that the tricky issues surrounding the plaintiff's knowledge or suspicion of a trespass are amplified further in a Lady Freyberg-type case, where the allegation of lease invalidity rests on as subjective a standard as well economics. The difficulty is obvious when one considers the opinions of the judges who dealt with the case throughout its history: in July 2002, Romaine J. found that there was no economical or profitable market prior to 1999 such that the Lease was valid; in February 2005, O’Leary J.A. 
supported that view, but Ritter and Conrad JJ.A. came to the contrary conclusion, meaning that the Lease was invalid; in November 2005, the Supreme Court of Canada refused leave to appeal, thereby conclusively settling the question. Of course, throughout this entire period, the litigants held opposing views: Freyberg (and her experts) believed that the Lease was invalid, while the defendants (and their experts) believed it was valid. None of the parties could have known conclusively that the Lease had terminated sometime prior to December 1999 until the Supreme Court of Canada ruled in November 2005.

On the issue of the plaintiff's knowledge, Kent J. rejected the approach of the Saskatchewan Court of Appeal in Williston, holding that Freyberg did not have the requisite knowledge of her legal rights until the Supreme Court of Canada denied leave, because only then did the parties know the lease was invalid.

\section{b. The Plaintiff's Conduct}

As noted above, the second type of inquiry relevant to determining whether leave and licence has been granted, is the plaintiff's conduct. In Williston, the plaintiff had written a number of letters to the defendants in which they stated their view that the lease was not valid. However, in none of the letters did the plaintiff demand that the defendants vacate the lands or cease producing hydrocarbons from the lands. When the plaintiff in Williston commenced its action, it sought only a declaration that the lease was invalid and an accounting. Much later, it amended its claim adding a claim in trespass.

The Saskatchewan Court of Appeal in Williston found that neither the (non-demand) letters nor the commencement of the lawsuit revoked the leave and licence that had been tacitly granted to the defendants, reasoning that once a plaintiff adopts the position that the lease has terminated, it must unequivocally demand that the defendants cease and desist from producing, or it will be found to have granted leave and licence:

In my opinion, one cannot have it both ways. If the position of the [plaintiff] is that the lease is at an end the [plaintiff] then demands possession of the land and minerals. Here that did not occur. The inescapable conclusion is that there was consent, tacit or express, on the facts of this case, that the [defendants] could remain in possession and pay the royalty pending a determination of the validity of the lease. That is exactly what happened.

In my opinion, the [defendants] occupied the land and produced the minerals with the consent of the [plaintiff]. It is noteworthy and not without significance that the [plaintiff] did not claim against the [defendants] in trespass until 2000, some eight years after the original letter disputing the validity of the lease.

The [plaintiff] was aware that the lease with T.D.L. had probably lapsed. It wrote to the [defendant] on March 11, 1992, questioning the validity of the lease but significantly did not request that the [defendants] get off the property. More importantly the [plaintiff] did not demand that Williston Wildcatters Corporation, or its successor in title, Williston, cease production of the oil from the 11-8 well. 
On April 11, 1992, the [plaintiff] sent a second letter to Williston in which it offered to grant the [defendants] a new lease (implying that the 1952 lease was at an end) but again significantly advised that it was "not yet requiring the operator vacate the property.” The letter requested that no further work be done on the 11-8 well. $^{66}$

\section{This second letter stated as follows:}

We would, therefore, request an Affidavit, sworn to by an officer of TDL, the operator at that time, setting out the status of operations during the period January 1990 to July 1990. If an Affidavit acceptable to ourselves is not forthcoming within 30 days of receipt of this letter, we will consider this lease to be terminated pursuant to its own terms and provisions therein.

Until such time as this matter is resolved, we believe that it is inappropriate for the Trust to respond to any requests from you with regard to further development involving these lands. ${ }^{67}$

The Saskatchewan Court of Appeal found that when the plaintiff notified the defendants that it believed the lease to be invalid, but did not unequivocally demand that they cease production and vacate the lands, the plaintiff thereby granted leave and licence to their continued production:

In my opinion, the [defendants] were on the land with the consent and leave and licence of the [plaintiff]. At no time did the [plaintiff] demand that the [defendants] give up possession of the property even though it claimed that the lease had terminated. ${ }^{68}$

The Court of Appeal also expressly found that the commencement of an action would not revoke leave and licence even if trespass were pleaded, especially if, after the claim was filed, there was no follow-up demand that the defendants cease production or vacate the lands:

Whether the filing of a claim in trespass can be said to be a revocation of licence given by a plaintiff depends on the facts and the circumstances of each case. The starting point for deciding whether the leave and licence was revoked is the filing and service of the claim for an accounting. This first claim did not plead trespass, and though trespass may be inferred through the claim for accounting, it is my opinion that something more is required to terminate the leave and licence in the circumstances. This is especially so when one examines the post-claim conduct of the appellant and the unitholders. Post-claim conduct is clearly relevant and in this case no request was made by the appellant for the respondent to stop production or vacate the lease. In fact, the facts as found by Gerein C.J. were completely to the contrary. Thus, on the facts of this case a revocation of the leave and licence did not occur in February 1993 when the appellant issued the statement of claim.

The claim was amended [seven years later] in 2000 to include a claim for trespass. In my opinion, that amendment did not constitute a revocation of the licence because there is no public interest concern 
underlying a finding of revocation of the licence as there was in C.P.R., and secondly, this amendment was not followed by any other specific request or requests to cease production or vacate the lease. ${ }^{69}$

The facts in Lady Freyberg were remarkably similar to those in Williston. Freyberg's original Statement of Claim, filed in 2001, sought only a declaration that the Lease was invalid and an accounting. ${ }^{70}$ Her Statement of Claim was amended specifically to plead trespass and conversion (pursuant to a case-management order requiring her to specify which torts she was alleging) only in December 2006, one month before the commencement of the second trial.

Commencing in 2001, Freyberg's English counsel had written to the defendants on numerous occasions, seeking information regarding the 6-3 Well, the Lease, and her rights thereunder. While some of these letters opined that the Lease was invalid and others stated that Freyberg's acceptance of royalty cheques was without prejudice to all her rights, none demanded that the defendants cease producing the 6-3 Well or vacate the Lands. Only on 14 February 2006 did Freyberg, through her counsel, actually demand the cessation of production. In response, the defendants shut-in the 6-3 Well on 17 February 2006.

Justice Kent did not accept the Saskatchewan Court of Appeal's view that an unequivocal demand to quit the Lands was required before leave and licence could be revoked. Instead, she hypothesized that from the time when Freyberg first had doubts about the validity of the Lease until the First Trial Decision was rendered, had she demanded that the defendants cease production from the 6-3 Well, the defendants would likely not have complied and instead might have sought court approval to continue production. Justice Kent further hypothesized that such approval would have been forthcoming because gas prices were so favourable at the time. Therefore, in Kent J.'s view, there would have been little utility in Freyberg demanding a cessation of production in this period.

Justice Kent also refused to adopt the Saskatchewan Court of Appeal's approach with respect to the type of action that a freehold owner has to commence or the type of demand she has to make to revoke leave and licence. She held that "[t]he only thing that Lady Freyberg did not do was say 'stop producing my gas'. In the face of clear pleadings which demanded compensation for all of the gas produced and the unrelenting pursuit of that claim through the courts, I do not accept that such a formality is required."71 Freyberg's pleading was sufficient to revoke leave and licence.

\section{c. The Defendant's Conduct}

The third important factor in the leave and licence analysis is the conduct of the defendants. In both Williston and Lady Freyberg, a prior enforceable lease had existed, the validity of which was subsequently disputed by the parties. Thus, the lessees had colour of

This is a common method of pleading such claims because actions for declarations are expressly excluded from becoming statute-barred in Alberta. See Limitations Act, R.S.A. 2000, c. L-12, ss. 1(i), 2; see John Bishop Ballem, The Oil and Gas Lease in Canada, 3d ed. (Toronto: University of Toronto Press, 1999) at 371.

Second Trial Decision, supra note 2 at para. 135. 
right. The Saskatchewan Court of Appeal noted that this "is a major factor that distinguishes this case from all available authority, that is, the existence of a prior lease between the parties the effect of which was in dispute. The [plaintiff] contends the lease was terminated in 1990 and the [defendant] contests that position. The [plaintiff] could not be as sure of a trespass as the plaintiffs in the cases discussed above."72

Freyberg argued that the defendants had dealt with her in bad faith or had been at least negligent in developing the 6-3 Well without first obtaining a title opinion that considered well economics. Justice Kent dismissed these allegations.

\section{PRACTICAL CONSIDERATIONS AND CONSEQUENCES}

Justice Kent's decision with respect to leave and licence did not fully canvass all the issues of interest to oil and gas industry participants. As with estoppel, Kent J. affirmed that leave and licence requires that the plaintiff have a high degree of knowledge of his or her legal rights. Justice Kent seemed to indicate that, for leave and licence to exist, the plaintiff must have full knowledge of their legal rights, which, for the validity of an oil and gas lease, requires a court decision. First, this raises the issue of whether leave and licence can ever be found to exist prior to a court determining whether the lease is valid and all avenues of appeal have been exhausted.

Other questions arise as to the business practicalities of what an oil and gas corporation's response should be in a Lady Freyberg-type situation. For example, when met with letters from a lessor raising issues as to the validity of the lease, but not going further and actually demanding that production stop, should the corporation err on the side of shutting in the well (sending a letter to the lessor for confirmation that they want production to continue) or putting the production funds in escrow? These are issues that remain to be decided, hopefully on a contextual basis cognizant of the business practicalities and sensitivities facing the oil and gas industry.

It should be remembered that cases such as Lady Freyberg, in which there was a preexisting valid lease, are very different from cases of "true" trespass. The difference is especially important in a case like Lady Freyberg, where the lease invalidity is alleged to flow from a subjective basis, like well economics. In such cases, as has been discussed, no one person can conclusively know whether or not a lease has terminated; people can only have opinions about that question. Therefore, even if a lessee wanted to, there is no way that the lessee can conclusively determine for itself whether or not it has the ability to continue producing the well. In those circumstances, one may legitimately argue that a higher standard is required of a lessor, such as an unequivocal demand that production cease. If a lessor wishes to upset the status quo (namely an apparently valid lease), why should that lessor not be put to making an unequivocal election? In such cases, if the Lady Freyberg precedent is followed (the precendent requiring a court decision as the basis for knowledge of lease invalidity), there may be little or no scope for a leave and licence defence ever applying, prior to a conclusive court determination of the validity of the lease. 


\section{CONCLUSION}

The Lady Freyberg case provides a fascinating insight on the evolution of oil and gas jurisprudence in Canada. Courts and litigants routinely struggle with the ever-changing realities of doing business in this "high risk, high reward” industry and also struggle with the application of historical case law to dynamic factual situations. There can be no question that a great deal has changed in the Canadian oil and gas industry in the last 25 years. Asset acquisitions and divestitures have become far more prevalent, as have employee turnover and corporate mergers and takeovers. All of these significant changes require that the courts approach cases in a flexible manner, sensitive to the fact that business realities may have changed since the establishment of historical precedents. 